\title{
Staří v. moderní a konzervatismus Edmunda Burka
}

\section{Ancients v. Moderns and Conservatism of Edmund Burke}

Jiří Baroš / baros@fss.muni.cz

Katedra politologie, Fakulta sociálních studií, Masarykova univerzita, Brno, CZ

\begin{abstract}
This study deals with the question of responses to the work of the founder and leading representative of British conservative thought Edmund Burke. It focuses in particular on political theorists who have not only considered Burke's work but have also managed to view their responses to it within the continuity of a tradition stretching back to the beginnings of political thought with Plato, Aristotle and Aquinas. The author therefore concentrates on figures such as Leo Strauss, Harvey C. Mansfield and Alasdair Maclntyre.
\end{abstract}

\section{Keywords}

conservatism, political thought, history of thought, Edmund Burke, Alan Sked, Leo Strauss, Harvey C. Mansfield, Alasdair Maclntyre 
Britský historik Alan Sked ve svém velice zajímavém článku sleduje vývoj britského konzervatismu na začátku 19. století prizmatem toho, jak tento koncipoval svou zahraniční a domácí politiku. Východiskem je mu (poměrně sporná) definice konzervatismu německého historika Hanse-Gerda Schumanna, který jej pokládá za „vědomé politické jednání, k němuž přistupují sociálně privilegované třídy, vrstvy či skupiny, aby zabezpečily instituce, v nichž je zakotveno jejich sociální postavení, proti snahám změnit normy převažující v politické sféře“. Tuto definici bohužel Sked nijak neproblematizuje, i když rozhodně za kritickou reflexi stojí. To, že v případě konzervatismu jde o „něco vědomého“, by šlo ještě aprobovat, ačkoliv není takto postižen rozdíl mezi konzervatismem, který je spíše postojem, a konzervatismem, který je spíše krédem. Byt’ v kontextu Skedova článku chápu, že se mu - jakožto historikovi - hodí definice konzervatismu jako „vědomého politického jednání" - ideje a představy ovlivňují sice jednání člověka, ale důležité je nakonec hodnocení, jak se tyto ideje a představy v realitě prakticky projevují -, je nicméně možno ke konzervatismu přistupovat (také a především) jako k myšlenkové soustavě, tj. z perspektivy dějin politického myšlení, kdy lze zkoumat její koherenci a také se s ní kriticky vyrovnávat. Právě o charakterizaci vnímání díla zakladatele a hlavního představitele britského konzervatismu Edmunda Burka, kterého Sked rozsáhle cituje, u autorů navazujících na předmoderní tradici politického myšlení (tj. na staré), tj. na Platóna (sem spadají autoři jako L. Strauss a H. Mansfield), Aristotela a Akvinského (A. MacIntyre), bych se rád - i vzhledem k mému odbornému zájmu - v této reakci na Skedův text zaměřil.

Ale ještě pár poznámek k východiskům Skedova textu, který charakterizuje to, jak do středu svého zájmu dává fenomén moci. Konzervatismus je totiž - dle jím přebrané definice - určitým (především mocenským) účelem vedené politické jednání „sociálně privilegovaných tříd, vrstev či skupin“. Tímto účelem je jim zabezpečení institucí, v nichž je zakotveno jejich výsadní „sociální postavení“ elit. Ačkoliv je jasné, že konzervativní ideová soustava může být tímto způsobem „sociálně privilegovanými“ užívána, ba zneužíána, vytrácí se kvůli této reduktivní definici pestrost motivace konzervativně smýšlejících lidí, kterou tak dobře popsal polský filosof Ryszard Legutko ${ }^{1}$ (ten konzervativce vidí bud' jako (a.) obhájce věčných hodnot, či (b.) jako strážce konkrétní civilizace a kultury, a konečně (c.) jako ty, kdo se snaží o ochranu bezprostřední reality, s níž se sžili). Implementace nějaké takové „ideální teorie“ (použiji-li Rawlsova, jakkoliv samozřejmě ve vztahu k Burkovi značně nepřesnému výrazu) konzervatismu v „neideálním světě“ (když zvláště ve světě politiky si člověk, jak kdysi uvedl Max Weber, „zahrává přímo s d'ábelskými mocnostmi“) je nutně značně obtížná a vystavená instrumentalizaci ze strany moci. To však ještě nic nemění na tom, že konzervativní vize sociálního univerza je víc než jen snaha o zabezpečení privilegií v sociálním konfliktu.

Bývá-li s konzervatismem spojováno spíše harmonické pojetí sociální reality (resp. status quo), i když to dobré bývá chápáno často jen jako to zděděné, může perspektiva zaměřená na společenský konflikt konzervatismu napomoci zbavit se určitých iluzí o uspořádání společnosti. Toto nebezpečí pozitivně přibarveného pohledu na současný stav nicméně platí především pro společnosti, které vnímají samy sebe jako ztělesnění

1 Legutko, Ryszard: Tři konzervatismy In: Ošklivost demokracie a jiné eseje. Brno 2009, s. 158-191. 
něčeho historicky výjimečného, co si právě proto žádá zachování. To byl i případ Británie $\mathrm{v}$ oné době $\mathrm{s}$ její $\mathrm{z}$ generace na generaci předávanou nepsanou ústavou. Sked ve svém příspěvku rozsáhle rozebírá, jak konzervativní vlády v tomto období blokovaly politické změny nějak související s Francouzskou revolucí (posouzení pravdivosti těchto tezí však musím ponechat historikům, zajímat mne totiž bude perspektiva dějin politických idejí). Je ostatně zajímavé, že i Alexis de Tocqueville považoval Burka za myslitele, jehož obhajoba aristokratické společnosti byla kvůli demokratické revoluci, která byla dle francouzského autora faktem prozřetelnosti (ačkoliv i demokracie si žádá pro své dobré fungování vlastní aristokracii, mající původ ve zkušenosti svobodného sdružování občanů; a pozitivním dědictvím z aristokratických dob je i církev), značně nerealistická. Navíc demokratické impulsy podle Tocquevilla alespoň částečně odpovídaly přirozenosti a nešlo v jejich případě nutně o perverzi přirozeného řádu věcí.

Určitou kvalifikaci si zasluhuje i poslední část uváděné definice konzervatismu, když je tento vymezován konfliktně vůči snahám změnit převažující politické normy. Je totiž nutno odlišovat reformu, která je konzervatismu vlastní, od revoluce, již odmítá. Tento nedostatek je nicméně napraven další Skedem zmiňovanou typologií (od Klause Epsteina) mezi (a.) konzervativci status quo, (b.) reformními konzervativci a (c.) reakcionáŕi. Společné je jim podle Skeda to, že pro všechny se hodiny (času) pohybují až př́liš rychle. Ostatně právě to je důvodem konzervativní reakce na neuvážený spěch všech pokrokářů.

Tolik několik poznámek k problematickým východiskům Skedova textu. A nyní již $\mathrm{k}$ něčemu, co u Skeda víceméně absentuje, totiž k intelektuálnímu zařazení nejslavněǰšího konzervativce všech dob, Edmunda Burka, a to na základě jeho srovnání s tradicí starých. Právě toto srovnání nám umožní lépe porozumět místu, které na pomyslné mapě politického myšlení zaujímá konzervatismus.

V návaznosti na slavného historika idejí Isaiaha Berlina bývá Burke spolu s dalšími mysliteli jako Vico, Malebranche nebo Herder označován za protiosvícence. Zeev Sternhall dokonce Burka považuje za otce neokonzervativcủ, kteří byli fascinováni mocí státu, a tak se vůbec nebojí - na rozdíl od takového Tocquevilla nebo Lorda Actona - jejích korumpujících tendencí. ${ }^{2} \mathrm{Ne}$ všichni autoři ovšem takto uvažují: tak např. podle Louise Duprého Burke nebyl reakcionář, nýbrž byl veskrze moderním autorem, který měl jen jiný pohled na vztah tehdejší „revoluční“ doby k minulosti a budoucnosti. ${ }^{3}$ Pavel Barša zase o Burkovi hovoří jako o dědici britského empirismu a skotského, tedy skeptického osvícenství, které se vymezovalo proti kontinentálnímu racionalismu a francouzskému, tj. dogmatickému osvícenství. ${ }^{4}$ Jak uvidíme ještě níže, podobnou intelektuální genealogii nabízí i jeden z největších morálních filosofů současnosti Alasdair MacIntyre. Jelikož Sked takovéto zařazení Burka do širší intelektuální historie bohužel nečiní, lze tento text chápat jako jisté doplnění jeho příspěvku. Hlavní otázka, která mne bude zajímat, se točí kolem toho, jaký byl Burkův vztah k politické filosofii starých, když Sked uvádí, že Burke kromě historického utilitarismu „akceptoval též teorii přirozeného práva“. Je tedy

2 Sternhall, Zeev: Les anti-Lumières. Paris 2006.

3 Dupré, Louis: The Enlightenment and the Intellectual Foundations of Modern Culture. New Haven 2004.

4 Barša, Pavel: Síla a rozum: spor realismu s idealismem v moderním politickém myšleni. Praha 2007, s. 36-41. 
možno mluvit o jakési kontinuitě mezi Burkem a myšlením starých, jak by snad někdo mohl Skedův text číst?

Leo Strauss věnoval Burkovi poslední kapitolu své knihy Natural Right and History. ${ }^{5}$ Přestože se Burke pokusil navrátit k předmoderní tradici přirozeného práva (úcta k britské ústavě se např. nápadně podobala úctě Cicerona k Římu), jeho pokus podle Strausse neuspěl. To však ještě neznamená, že by Strauss negativně hodnotil všechny Burkovy výtky vưči francouzským revolucionářům, jak to ostatně dokládá celá první třetina Straussovy tematizace Burka, která je mu do značné míry nakloněna. S jistým zjednodušením je možno dokonce říct, jak uvádí Steven J. Lenzner, že podle Strausse měl Burke „správné politické názory, ovšem ze špatných důvodů“. ${ }^{6}$ Pokus o kombinaci prvků klasického přirozeného práva s moderními koncepty jako přirozený stav, přirozená práva či proto-utilitaristický koncept štěstí (a potřeb) neměl nicméně pro svou velkou nesourodost valnou naději na úspěch. U Burka dochází k významným posunům od názorů klasických politických filosofů, což lze dokumentovat zvláště na jeho charakterizaci vztahu teorie a praxe. Zatímco druhá část (tj. odstavce 14-23) Straussovy kapitoly (ještě jen) implicitně naznačuje některé Burkovy odchylky od starých (např. jeho názor na nezdravý odstup teorie k určité partikulární příčině či zemi, což je pro efektivní činnost státníka nemyslitelné; tezi, že odhalení limitů politické praxe teorií ohrožuje plnou oddanost praxi; možnost užití omylů, předsudků a pověr ze strany státníka), ty jsou již plně odhaleny v části třetí.

Burkovo rozlišení teorie a praxe je podle Strausse radikálně odlišné od Aristotelova, jelikož není založeno na jasném přesvědčení o konečné nadřazenosti teorie a teoretického života. Již ve svém raném díle Burke de facto popřel konvertibilitu transcendentálií, když analyzoval pojem krásy bez ohledu na jeho souvislost s dokonalostí, mírou, ctností či řádem. Pokoušel se o jisté osvobození citu a instinktu vůči rozumu, což vedlo k určitému znevážení rozumu. Jeho „opozice vůči modernímu racionalismu se nepostřehnutelně mění v opozici vůči racionalismu jako takovému“. Zvláště do očí bijící jsou tyto rozdíly podle Strausse u Burkova chápání pojmu ústavy. Odmítá totiž názor, že ústava může být vytvořena, ve prospěch názoru, že ústava musí „vyrůst“. Nejlepší společenské zřízení nemůže být dílem moudrého zákonodárce nebo zakladatele, kdy by se jím vytvořená ústava z hlediska svého cíle pokoušela maximálně uspokojit požadavky směřující k naplnění lidské přirozenosti nebo by napodobovala vzorec přírody. To však neznamená, že by - na rozdíl od toho, co si myslí Burke - musela vzniknout „přirozeným způsobem“, tj. nereflektivně, kontinuálně a pomalu. I když státnická prozíravost může modifikovat částečně vznik ústavy, nehovoří Burke ještě o nějakém racionálním „historickém procesu“, který by tento vznik způsoboval. Otevírá ale podle Strausse brány „objevu Historie“ a nachází se u něj podobný mechanismus vysvětlení jako pojem neviditelné ruky trhu. Procesy, které nejsou řízeny lidskou reflexí, jsou nadřazené co do moudrosti svých účinků produktům reflexe (ústava ztělesňuje moudrost věků). Podle Strausse to byla právě „Burkova interpretace jeho konzervatismu“, co připravilo cestu přístupu, jenž je vzdálenější klasickému myšlení než radikalismus teoretiků francouzské revoluce. Přestože

5 Dále shrnuji Strauss, Leo: Natural Right and History. Chicago 1953, s. 294-323.

6 Lenzner, Steven J.: Strauss's Three Burkes. The Problem of Edmund Burke in Natural Right and History, Political Theory 19, č. 3, 1991, s. 364-390. 
Burke někdy též uznává, že by britská ústava měla být měřena vyšším standardem přirozeného práva, dělá to pouze v omezené míře, když zároveň tvrdí, že její autorita vyplývá vlastně z plynutí času. Teorie je u něj znevážena ve prospěch praxe. Nejvyšší formou praxe se mu přitom stává jakýsi „kvazi-přirozený proces nijak nekontrolovaný reflexí“. Proto Burke podle Strausse vyšlapal cestu velkým filosofiím dějin. Politická teorie se stala jen snahou porozumět praxi a ztratila vazbu na celek i snahu objevit to, co by mělo být.

I Straussovi příznivě naklonění komentátoři obvykle zmiňují, že poslední část jeho textu je k Burkovi až příliš nespravedlivá, zvláště když Burke nic nenamítal proti tvorbě nové ústavy v nově ustavených Spojených státech amerických. Přesto Straussova kritika jako celek zůstává rukavicí hozenou Burkovým obhájcům, protože ukazuje, jak poznamenal Steven J. Lenzner, který nabídl asi nejpropracovanější kritiku Straussovy kritiky, nutně omezený horizont státníka. ${ }^{7}$ Vliv Strausse se projevil i u dalšího známého straussiána, harvardského historika politických idejí Harveyho C. Mansfielda, Jr., jehož některé oproti Straussovi vyrovnanější, byt také kritické myšlenky bych rád dále představil. ${ }^{8}$ I podle Mansfielda totiž platí, že Burke - přestože často odkazuje na rozumnost starých - je nikde nenabízí jako průvodce, kteří by mohli ukázat cestu z krize, do které nás moderní filosofové dostali. Vůbec si nedává práci, aby rozlišil dobrou spekulaci od špatné, a téměř apriorně se vyhýbá tomu, aby kritizoval filosofii na jejím vlastním poli. Přesto jeho dílo nějaké první principy nutně obsahuje: podle Mansfielda jsou jimi (a.) rozumnost a (b.) oslava génia britské ústavy.

Nadřazenost (prakticky orientované) rozumnosti nad teorií je podle Mansfielda u Burka spojena s předpokladem, že génius britské ústavy dokázal zaručit morálnost rozumnosti (není sobeckou vypočítavostí), a tak ospravedlňuje i její suverenitu. Zakládání nového režimu, které bylo vždy považováno za nejdůležitější politický čin, nemůže být nicméně vedeno jen praktickou rozvahou, jelikož vyžaduje jistou teorii nejlepšího politického uspořádání. Burkem ale tuto otázku vůbec netematizoval. Tím se jeho politické dílo stává nejen pro nově založené režimy, ale i ty režimy, které se snaží i po svém vzniku nacházet nejlepší možnou interpretaci svého formativního dokumentu, v tomto bodě značně neužitečným. Na rozdíl od starých nedává ústava jakožto projev zakladatelského aktu formu vládnoucím i ovládaným, nýbrž ta je podle Burka závislá na okolnostech a zvycích země, které se časem mění a s nimi se pak proměňuje i ona. Burke tak podle Mansfielda zásadně dává prioritu tomu, co je „aktuální, užitečné a efektivní“ nad tím, co je formálně správné. Přestože je lidské zřízení podle Burka podřízeno přirozenému zákonu, na rozdíl od Tomáše Akvinského či Hobbese se nijak nesnaží specifikovat jeho obsah, který se podle něj ukazuje jen v konkrétních věcech a okolnostech. Rozdíl od starých je dále patrný zejména v tom, že jak Burkův přirozený zákon „ponechává suverenitu rozumnosti, dává výsadní postavení okolnostem, nijak nevyžaduje překročení sebestředných náklonností člověka a konečně je příznivě nakloněn předsudkům“. Jak uvádí Mansfield, Aristoteles by oproti Burkovi nikdy neměl takovou důvěru v latentní moudrost předsudků lidu. Názory lidí totiž stojí většinou v opozici vůči sobě, a proto jsou tak důležité

7 Lenzner, S. J.: Strauss's Three Burkes, s. 377.

8 Harvey, Mansfield: Edmund Burke. In: History of Political Philosophy. Eds. L. Strauss, Leo; J. Cropsey. Chicago 1987, s. 687-709. 
(filosofovy) korekce i to, že se státník pokusí vytvořit ze správných východisek určitých předsudků celistvější pohled.

Výše uvedené kritiky Burka je třeba číst jako určité vyjasnění toho, k čemu Sked také dochází, když píše, že „přirozené právo se u Burka ztotožňuje s právem zvykovým“, i když si zásadní odlišnosti Burkova konzervatismu od myšlení starých nevšímá. Výše uvedená teze je totiž v radikálním rozporu s chápáním filosofie u starých, která byla podle Strausse cestou od toho, co máme jen od předků, k tomu, co je dobré na základě své přirozenosti. Byt’ Burke mimořádně zajímavým způsobem hovoří o roli náboženství ve společnosti (a to způsobem tak podnětným, že by se podle mého názoru mnohé jeho argumenty daly použít i dnes proti principiálním odpůrcům církevních restitucí), jeho pojetí se odlišuje radikálním způsobem od aristotelsko-tomistické tradice, jak na to upozornil Alasdair MacIntyre. Ten nejprve ve své slavné knize Ztráta ctnosti kritizoval burkovský pojem tradice, který je konzervativci dáván do protikladu k rozumu a konfliktu. ${ }^{9}$ Podle MacIntyra se každé uvažování ale odehrává „v kontextu nějakého tradičního způsobu myšlení, který kritikou a vynalézavostí překračuje omezení toho, o čem se až dosud v rámci této tradice uvažovalo“. Nepřetržitý konflikt je tak znakem toho, že je tradice živá. Takovouto živou tradici lze chápat jako „historicky rozsáhlou a do společnosti integrovanou diskusi“. Podle MacIntyra moderní konzervativci nemají se starší (tj. aristotelskou) tradicí až zase tak mnoho společného, jelikož jim nakonec jde jen o „uchovávání starších variant liberálního individualismu místo těch novějších“.

V pozdějším díle se MacIntyrovi podařilo začlenit Burka do své komplexní genealogie (praktické) racionality a spravedlnosti (jednotlivá pojetí spravedlnosti jsou totiž vždy spjata s určitou koncepcí racionality) v rámci západní kultury. ${ }^{10} \mathrm{Jde}$ mu v ní o to, aby ukázal, jak je racionalita ustavena tradicí a jak také ustanovuje tradici. Tradice je podle něho „argument rozprostřený v čase, ve kterém jsou určité základní shody (re)definovány skrze dva druhy konfliktů“, a to vnějšími (s kritiky a nepřáteli, kteří nepatří do tradice) a vnitřrními (ty se týkají vnitřních interpretačních debat) konflikty. Kromě (a.) aristotelské, (b.) augustiniánské a (c.) liberální tradice MacIntyre rozeznává konečně i (d.) tradici skotského osvícenství, do níž situuje Burkeho dílo. Všechny tyto tradice se zásadním zpo̊sobem podílely na konstrukci naší současné kultury. Skotské osvícenství pak podle MacIntyra vyrostlo z půdy, v níž se jakékoliv odkazy na sdílené dobro, typické pro dřívější období, staly iluzorními. Panovník byl legitimován pouze tím, že namísto prosazování nějakého dobra zabraňoval škodám a přinášel užitek poddaným. Kromě instituce moderního státu měla užitky lidem přinášet také tržní ekonomika. Vášně a zájmy měly být ve společnosti uspořádány tak, aby „umožnily určitou vzájemnost při naplňování uspokojení a užitků“. Burkova rétorika měla $\mathrm{v}$ tomto kontextu podle MacIntyra „hájit takto ustavený řád, přičemž (v rámci něho) bylo přípustné se dovolávat pouze těch hodnot, které (již) byly uznány v rámci výměn užitků a uspokojení (uvnitř tohoto řádu)“. Burke podle MacIntyra zaútočil na všechny teoretické principy, které by měly mít jiný zdroj autority než ten, co se nachází uvnitř řádu. Jakýkoliv nesouhlas s řádem, který přece musí vyjadřovat „soulad

9 MacIntyre, Alasdair: Ztráta ctnosti. Praha 2004, s. 258-259.

10 Týž: Whose Justice? Which Rationality? Notre Dame 1988, s. 12, 209-240, 353-354. 
zájmů a vášní jeho účastníkư“, musí být interpretován jako zločin či rebelie. Problémem Burkova pojetí tradice je tak podle MacIntyra to, že se snaží o ospravedlnění řádu bez reflexe a teoretizování, které by bylo dílem tradice a uvnitř jíž by také probíhalo. Přestože by se měl burkovský řád neustále přizpůsobovat okolnostem, je jeho pojetí tradice málo dynamické a nereflexivní. Tradice totiž Burkovi ztělesňuje „moudrost bez reflexe“, což je v ostrém kontrastu nejen se starými, ale i s dílem velkého myslitele tradice, jímž byl kardinál John Henry Newman. I když mnoho Burkových postřehů neztratilo ani dnes na relevanci, přesvědčivější rámec pro (orientaci ve) spolužití lidí nabízí podle mého názoru spíše autoři jako MacIntyre a Newman. Zdá se, že příspěvek Skeda nabízí jisté doplnění (a také potvrzení) tohoto pohledu intelektuální historie, když ukazuje, jak Burkem započatá tradice anglického konzervatismu byla využita též k (až) př́lišné petrifikaci společenského vývoje.

\section{Ancient v. Modern and Conservatism of Edmund Burke}

This study deals with the question of responses to the work of the founder and leading representative of British conservative thought Edmund Burke. It focuses in particular on political theorists who have not only considered Burke's work but have also managed to view their responses to it within the continuity of a tradition stretching back to the beginnings of political thought that can be found with Plato, Aristole and Aquinas. The author therefore concentrates on figures such as Leo Strauss, Harvey C. Mansfield and Alasdair MacIntyre as well as John Henry Newman. He mainly deals with Burke's conception of constitution and tradition, formulating a thesis that for Burke tradition embodies "wisdom without reflection", which is in stark contrast to the conception of tradition among the aforementioned classical writers on philosophical thought. The author of the study believes that although many of Burke's observations have not lost their relevance, a more convincing framework for (orientation in) co-existence is offered by thinkers such as MacIntyre and Newman. In accordance with Alan Sked's analysis, he concludes that the tradition of English conservatism initiated by Burke may also have led to an excessive fossilization of social development. 
